\title{
3-Türkçenin yabancı dil olarak öğretiminde anlama becerileri (dinleme ve okuma)
}

\author{
Ahmet BAŞKAN' 1 \\ Mete Yusuf USTABULUT2²
}

\begin{abstract}
APA: Başkan, A.; Ustabulut, M. Y. (2020). Türkçenin yabancı dil olarak öğretiminde anlama becerileri (dinleme ve okuma). RumeliDE Dil ve Edebiyat Araştırmaları Dergisi, (21), 39-55. DOI: 10.29000/rumelide.835294.
\end{abstract}

\section{$\ddot{\mathbf{O z}}$}

İnsan, sosyal bir varlıktır ve toplumsallı̆ının bir sonucu olarak diğer kişilerle sürekli iletişim halindedir. Bu iletişimde birey, anlama ve anlatma becerilerini kullanır. Dinleme ve okuma, anlama becerileri kapsamına girer. Kişilerin ana dillerindeki yazılı veya sözlü ifadeleri anlamalarını sağlayan bu beceriler, Türkçenin yabancı dil olarak öğretiminde de önemli yer tutar. Bu durumdan hareketle bu çalışmada, anlama becerileri olan dinleme ve okuma becerileri üzerinde durulmuştur. Bu kapsamda, her iki becerinin ne olduğuna, iletişimde nasıl bir rol oynadığına ilişkin bilgiler sunulmuş ve bu becerilerin Türkçenin yabancı dil olarak öğretimi açısından yeri ve öneminden bahsedilmiştir. Bunun yanında çalışmada, ana dili öğretimi ile Türkçenin yabancı dil olarak öğretiminde anlama becerilerinin verilmesinde ne gibi farklılıklar olduğuna ilişkin bilgilere de yer verilmiştir. Çalışma ile dinleme ve okuma becerilerinin kapsamının ve sınırlarının çizilmesi, yabancı dil olarak Türkçe öğretiminde bu becerilerin yeri ve öneminin belirlenmesi amacıyla kapsamlı bir literatür taraması yapılmıştır. Buna göre, öğrencilerin işitsel mesajları alabilecekleri sosyal ortamlara daha fazla girmeleri, dinleme becerisinin gelişiminde daha hızlı mesafe kat edilmesini sağlayabilir. Ayrıca sunulan dinleme materyallerinin görsel unsurlarla, jest ve mimiklerle desteklenmesi de dinleme becerisinin gelişimine katkı sağlayabilir. Türkçenin yabancı dil olarak öğretiminde okuma becerisinin geliştirilmesi büyük önem taşıdı̆̆ı ve okuma becerisinin gelişmesiyle diğer becerilerinin gelişimine de bir zemin hazırlanacağı ifade edilebilir. Yabancı dil öğretiminde okuma becerisinin geliştirilmesi için öncelikle bireylerin hedef dildeki metinleri doğru biçimde anlamaları gerekmektedir. Bu okuduğunu anlama işleminde kişinin kelime hazinesinin yeterli düzeyde olması, cümle yapısının ve dil bilgisi özelliklerinin öğrenci tarafından belirli bir düzeyde bilinmesi gerekir. Ayrıca, okunan metinlerdeki içeriğin de öğrencilerin ön bilgileri ile uyumlu olması önemlidir.

Anahtar kelimeler: Anlama becerileri, Türkçenin yabancı dil olarak öğretimi, dinleme, okuma

\section{Comprehension skills in teaching Turkish as a foreign language (listening and reading)}

\begin{abstract}
Human is a social being and as a result of his sociality he is in constant communication with other people. In this communication, the individual uses comprehension and expression skills. Listening

1 Dr. Öğr. Üyesi, Dicle Üniversitesi, Ziya Gökalp Eğitim Fakültesi, Türkçe ve Sosyal Bilimler Bölümü, Türkçe Eğitimi ABD (Diyarbakır, Türkiye), ahmetbaskanturkce@gmail.com, ORCID ID: oooo-0003-4028-9067 [Araştırma makalesi, Makale kayit tarihi: 09.09.2020-kabul tarihi: 20.12.2020; DOI: 10.29000/rumelide.835294]

2 Dr. Öğr. Üyesi, Bayburt Üniversitesi, Eğitim Fakültesi, Türkçe ve Sosyal Bilimler Bölümü, Türkçe Eğitimi ABD (Bayburt, Türkiye), meteustabulut@bayburt.edu.tr , ORCID ID: 0000-0002-8864-645X
\end{abstract}

Adres

İstanbul Medeniyet Üniversitesi, Eğitim Bilimleri Fakültesi, Türkçe ve Sosyal Bilimler Eğitimi Bölümü, Türkçe Ĕ̆itimi ABD Cevizli Kampüsü, Kartal-İstanbul/TÜRKIYYE e-posta: editor@rumelide.com
Address

İstanbul Medeniyet University, Faculty of Education Sciences,

Turkish and Social Scinces Education, Turkish Language Teaching

Education, Cevizli Campus, Kartal-İstanbul /TURKEY

e-mail: editor@rumelide.com 
and reading are included in comprehension skills. These skills, which enable people to understand written or oral expressions in their mother tongue, also play an important role in teaching Turkish as a foreign language. From this point of view, this study focused on listening and reading skills, which are comprehension skills. In this context, information about what both skills are and what role they play in communication is presented and the place and importance of these skills for teaching Turkish as a foreign language is mentioned. In addition, the study also included information on the differences between mother tongue teaching and teaching comprehension skills in teaching Turkish as a foreign language. A comprehensive literature review was conducted in order to draw the scope and boundaries of listening and reading skills with the study and to determine the place and importance of these skills in teaching Turkish as a foreign language. Accordingly, the more students enter social environments where they can receive auditory messages, the faster the distance can be covered in the development of listening skill. In addition, supporting the presented listening materials with visual elements and gestures may contribute to the development of listening skill. It can be stated that the development of reading skill is of great importance in teaching Turkish as a foreign language and that the development of reading skill will prepare a ground for the development of other skills. In order to develop reading skills in foreign language teaching, individuals must first understand the texts in the target language correctly. In this reading comprehension process, the person's vocabulary must be at a sufficient level, sentence structure and grammar characteristics must be known by the student at a certain level. In addition, it is important that the content of the texts read is compatible with the prior knowledge of the students.

Keywords: Comprehension skills, teaching Turkish as a foreign language, listening, reading

\section{Dinleme}

Anlama becerileri arasında yer alan dinleme becerisi, günlük hayatta en çok başvurduğumuz becerilerin başında yer almaktadır. Yapılan araştırmalar, öğrendiklerimizin çok büyük bir bölümünü dinleme yoluyla elde ettiğimizi ifade etmektedir. Bu durum, yeterli düzeyde dinleme becerisine sahip olmayan bir kişinin zihinsel kapasite eksiği olmamasına verimsiz bir öğrenme süreci yaşayacağ anlamını taşımaktadır (Çifçi, 2001: 169). Benzer biçimde Akyol (2006) da bireylerin sahip oldukları bilgilerin yaklaşık \%8o'lık bir bölümünü dinleyerek elde ettiklerini ifade etmektedir. Tüm bu veriler, dinleme becerisinin öğrenme sürecinde ne denli önemli olduğunu ortaya koymaktadır (Durmuş, 2013: 142).

Literatürde dinleme ile ilgili aşağıdaki tanımlara rastlanmıştır:

"Seslerin ve varsa konuşma görüntülerinin farkında olmayla ve onlara dikkati vermeyle başlayan, belli işitsel işaretlerin tanınması ve hatırlanmasıyla süren ve anlamlandırılmasıyla son bulan psikolojik bir süreç” (Ergin ve Birol, 2000: 115).

"işitilenlerden bir anlam yaratma, anlaşllanları gerektiğinde kullanmak üzere saklama" (Sever, 2004),

"konuşan ya da sesli okuyan bir kişinin vermek istediği sözlü mesajları doğru bir şekilde anlama" (Özbay, 2005).

"görsel ve işitsel simgelere verilen bir tepki” (Ergin, 2008)

“iletişim ağına eklenme veya katılma biçimi” (Gündüz ve Şimşek, 2014: 22) 
Tanımlardan hareketle, dinlemenin zihinsel ve psikolojik bir işlem olduğu, bilişsel faaliyetleri içerdiği, iletişimsel anlamlandırma işinin yerine getirilmesi için gerekli olduğu sonuçlarına ulaşılabilir (Sarikaya, 2018: 56). Ayrıca dinlemeye ilişkin yapılan tanımlar incelendiğinde bazı ortak unsurları vurguladıkları görülmektedir. Bu unsurlar şöyle sıralanabilir:

- İletileri doğru bir şekilde anlama ve yorumlama çabası,

- Dilin dört temel işlevinden biri olma,

- Kişiler arası iletişim unsuru olma,

- Belirli bir amaç doğrultusunda yapılma,

- İnsanın seçme özgürlüğünün bir yansıması olma,

- İşitmeyi de içine alan bir etkinlik olma,

- Öğrenilebilen ve öğrenilmesi gereken bir dil becerisi olma,

- İnsan beyninin çeşitli bilişsel süreçlerini gerektirme,

- Çok farklı boyutları olan bir olgu olma,

- Karmaşık ve aktif bir süreci içerme (Epçaçan, 2013: 334).

İletişimin iki boyutu vardır. Bunlar konuşma (ifade etme) ve dinlemedir (algılamadır). Birçok Batı medeniyetinde "konuşma" uzun yllar boyunca iletişimin en önemli unsuru olarak kabul edilmiştir. İletişimle ilgili yazılan kitaplarda hep iyi bir konuşmacı olmak üzerinde durulmuştur. Buna karşın dinleyiciler yalnızca konuşmacıların amaçlarına hizmet eden kişiler olarak değerlendirilmiştir. Birçok insan çok iyi konuşmacılar oldukları için ödüller almış ve takdir görmüştür. Ancak çok az insan iyi dinleyici oldukları için onurlandırılmıştır. Ancak günümüzde insanlar, dinlemenin de en az konuşma kadar insanlar arası iletişimin sağlanmasında ve hatta profesyonel iş ilişkilerinde etkili olduğunun farkına varmışlardır. Bugün dinleme yetkinliklerine sahip olmak, iş bulmak ve işlerde başarılı olmak için en önde gelen yeterliklerden biri olarak kabul edilmektedir. Bu gücün keşfedilmesinin ardından dinlemenin bilinçli bir biçimde yapılmasına ilişkin çalışmalar yapılmaya başlanmıştır (Purdy, 1997; Ford, Wolvin ve Chung, 2000).

$\mathrm{Bu}$ bağlamda araştırmacılar, geçmişte inandıklarının aksine, dinlemenin pasif değil aktif bir süreç olduğunun ve bu becerisinin diğer becerileri de etkilediğinin farkına varmışlardır (Vandergrift ve Goh, 2012: 304). Söz gelimi Tomlinson (2011) dinleme becerisinin gelişimi tam olarak tamamlanmadan okuma öğretiminin ertelenmesi gerektiğini ifade etmektedir. Benzer biçimde Özbay’a (2009a: 63) göre dinleme becerisi yetersiz olan bir bireyin anlama becerisi de yetersiz demektir. Anlama becerisi eksik olan bir kimsenin de anlatma becerisi tam gelişmemiştir. Mete ve Bağcı Ayrancı (2016: 4961) da anlama becerisi içerisinde yer alan dinleme becerisinin diğer becerilerden kesin olarak ayrılamayacağını vurgulamış ve bir dil becerisinin gelişiminin dolaylı olarak diğer dil becerilerini de etkileyeceğini ifade etmişlerdir. Şahin (2011: 179) ise hem ilk öğrenilen beceri olması hem de tüm alanlarda ilk öğrenmelerin çoğunlukla dinlemeye dayanıyor olmasından yola çlkarak dinlemenin dil öğretiminin temelinde yer alması gerektiğini belirtmiştir.

Dinleme ilk edinilen dil becerisidir. Kişi hem doğuştan gelen dil becerisini geliştirirken hem de ana dilini öğrenirken dinleme becerisinden faydalanır (Bulut, 2013: 3). Bir başka ifadeyle temel dil becerilerinden biri olan dinleme, doğum öncesi anne karnında başlamakta, doğumdan sonra giderek gelişerek tüm diğer beceri alanlarına zemin oluşturmaktadır (Güneş, 2013).

\footnotetext{
Adres $\mid$ Address

İstanbul Medeniyet Üniversitesi, Eğitim Bilimleri Fakültesi, Türkçe İstanbul Medeniyet University, Faculty of Education Sciences, ve Sosyal Bilimler Eğitimi Bölümü, Türkce Eğitimi ABD Cevizli Turkish and Social Scinces Education, Turkish Language Teaching Kampüsü, Kartal-İstanbul/TÜRKIYE Education, Cevizli Campus, Kartal-İstanbul /TURKEY e-posta: editor@rumelide.com 1 e-mail: editor@rumelide.com
} 
Bireylerin gerek öğrenimleri süresince gerekse hayatları boyunca öğrenme ve anlamasının en önemli yollarından biri dinlemedir. Yaşam boyunca birçok bilgi, dinleyerek ve izleyerek öğrenilir (Doğan ve Erdem, 2017: 65). Kişilerin doğumuyla birlikte en çok kullandığı duyu organları kulak ve gözleridir. Bu organlar, öğrenmenin ve bilgi sahibi olmanın etkili araçlarıdır (Özbay, 2009a: 40). Dinleme becerisi öncelikle çocuğun ilk eğitimini aldığı ailede başlar, sonrasında örgün eğitim ile birlikte planlı ve programlı olarak geliştirilmeye çalışılır (Kurudayıŏlu ve Kana, 2013: 246).

Dinlemenin temelinde, konuşan veya sesli şekilde okuyan kişiye ait duygu ve düşüncelerin, ses-söz dizimi ilişkisi çerçevesinde algılanması ve anlamlandırılması yatmaktadır (Özbay ve Çetin, 2011: 155). Dinlemenin gerçekleşebilmesi için sağlıklı bir işitmeye gereksinim vardır. Dışarıdan gelen seslerin duyulması olan işitme, fizyolojik bir olaydır ve bu yönüyle dinlemenin ön şartıdır. Çünkü dinleme, işitilen seslerin zihinde yapılandırılarak anlam bulmasıdır. Dolayısıyla tam bir dinlemenin oluşabilmesi için kişinin zihinsel ve fiziksel süreçlerinin tamamının yeterli seviyede gelişmesi gerekmektedir. Bu şartları sağlayan bireylerin tümü, hem sosyal hem de akademik hayatında en çok dinlemeye zaman ayırmaktadır (Karakuş Tayşi, 2017: 321). Yazılı materyallerin büyük bir öneme sahip olduğu okullarda bile öğrenmenin gerçekleşmesinde dinleme çok önemli bir yer tutar. Günlük hayatta da en çok kullanılan dil becerisi dinleme becerisidir (Doğan, 2013: 12).

Doğuştan getirilen bir beceri alanı da olsa dinleme becerisinin kazanımı ve gelişimi bir eğitim sürecini gerekli kllmaktadır (Maden ve Durukan, 2011: 103). Başka bir deyişle, dinleme becerisinin geliştirilmesi ancak ve ancak bilinçli bir eğitim süreciyle mümkündür. Ayrıca bireyin çevresini doğru bir şekilde algılayarak içinde bulunduğu sosyal çevreye uyum sağlamasında dinleme becerisinin önemli bir payı olduğu söylenebilir (Çiftçi, 2007: 231).

Gündüz ve Şimşek (2014: 20-21) dinlemenin bireysel ve toplumsal yararlarını şu şekilde özetlemişlerdir:

Dinleme, sağlıklı bir güven ortamı oluşturur, güven duygumuzu geliştirir, bizi dinlediğini fark ettiğimiz kişilere olan güvenimizi arttırır.

Dinleme, öz saygıyı geliştirir. Bu da kendimizi daha iyi hissetmemizi sağlar.

Dinleme, akademik başarıyı arttırır. Kişiler, derslerini dinleyerek hedefledikleri başarıya ulaşır.

Dinleme iş dünyasında da verimliliği arttırır, çalışma ortamını güzelleştirir. İşverenin çalıştırdığı insanlara kulak vermesi, çalışanların birbirlerinin söylediklerini anlamaya çalışması iş başarısını beraberinde getirir.

Dinleme bir iç disiplin oluşturur. Motivasyonumuzu arttırarak odaklanmamıza yardımcı olur.

Sosyal ilişkilerde ve aile yaşamında düzeni ve huzuru sağlar.

Benzer biçimde Doğan ve Erdem (2018) de dinleme becerisinin günlük hayatta bir konuda bilgi edinmek, güzel vakit geçirmek, karşlaşılan olaylara eleştirel gözle bakmak, eleştiri almak, başka insanların tecrübelerinden ve anlayışlarından faydalanmak, toplumla iletişim kurmak, bir konuya hâkim olmak, ufkunu genişletmek, bir sosyal ilişki oluşturmak, başka insanların fikirlerini değerlendirmek ve onlara saygı göstermek gibi birçok yararı olduğunu belirtmişlerdir. Ayrıca kişiler arası iletişim çatışmaları, dinleme becerisini geliştirmeye duyulan ihtiyacı göstermesi bakımından önemlidir (Melanlığlu, 2011: 69). 


\subsection{Dinleme türleri}

Bireylerin dinleme becerilerinin geliştirilebilmesi için sahip oldukları dinleme türünün/türlerinin belirlenmesi gerekir (Kaya, 2014). Literatür incelendiğinde dinleme türlerine ilişkin birçok farklı sinıflamanın olduğu görülmüş, bu sınıflamalara Tablo 1'de yer verilmiştir:

Tablo 1: Kaynaklara Göre Dinleme Türleri

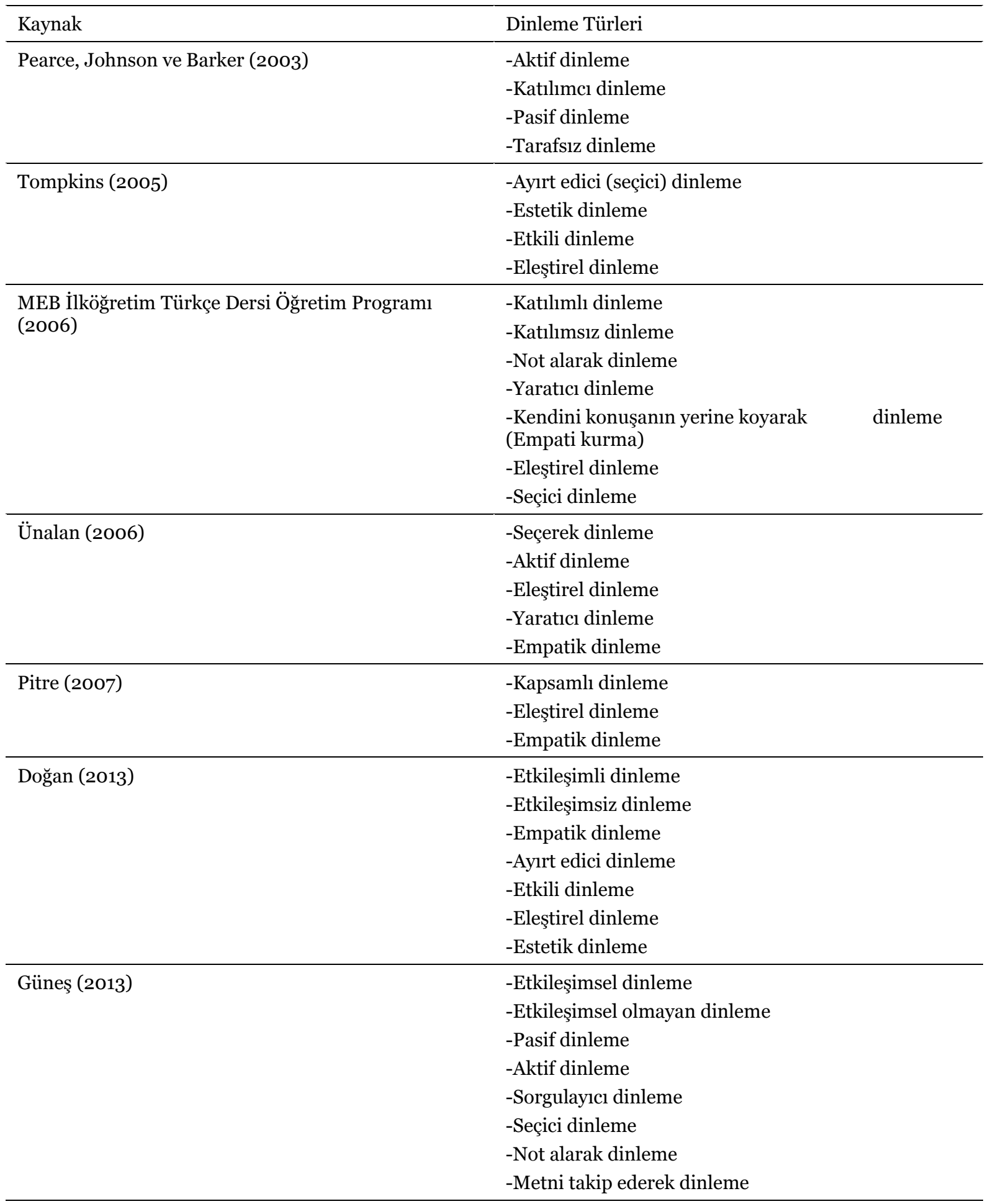




\begin{tabular}{ll}
\hline Ungan (2013) & -Gönüllü dinleme \\
& -Amaçlı dinleme \\
& -Stratejik dinleme \\
& -Eleştirel dinleme \\
& -Haz almak için dinleme \\
\hline Akyol (2014) & -Aktif dinleme \\
& -Diyalog ve sunuya dayalı dinleme \\
& -Stratejik dinleme \\
& -Amaçl dinleme \\
\hline
\end{tabular}

Tabloda görüldüğü gibi, dinleme türleri benzer özellikleri ifade etseler de kaynaklarda farklı şekillerde adlandırılmaktadır. Bu sınıflamaların birçoğunda ortak olan dinleme türlerine ilişkin ayrıntılara aşağıda yer verilmiştir:

Katılımlı (Aktif) Dinleme: Katılımlı dinleme, dinleme sürecinde zihinde oluşan soruların konuşmacıya iletilerek dinlenilenlerin daha iyi kavranmasıdır. Dinlenilenlerin ve soruların konuşmacıya yansıtılarak karşısındakine dinlediğini hissettirme, konuşmacının rahatlamasını ve iletişimin amacına ulaşmasını da sağlar (MEB, 2006: 62). Başka bir deyişle katılımlı dinleme, karşımızdaki kişiyi onu dinlediğimizi hissettirmeye dayanır (Yalçın, 2002: 132). Katılımcı dinleyiciler, dikkatinin çoğunu konuşan kişinin kullandıkları sözcüklere ve konuşmanın amacına verir (Ateş ve Ercan, 2015: 110).

Katılımsız Dinleme: Katılımsız dinlemede amaç dinleme/izleme sürecinde öğrencilerin dinledikleri üzerinde düşünmelerini sağlayarak zihinsel faaliyetlerini etkin kılmaktır. Uygulamada ise dinlenilen metnin bir süreçten mi bahsettiği, yoksa bir açılama mı getirdiği belirlenir. Metnin türüne ve metinden elde etmek istenilenlere uygun olarak zihinde "Kim, ne, nereye, ne zaman, nasıl?" gibi sorulara cevap bulmaları için öğrenciler yönlendirilir (MEB, 2006: 62).

Not Alarak Dinleme: Not alarak dinlemede amaç dinlenenlerin/izlenenlerin daha kolay anlaşılmasını ve hatırlanmasını sağlamaktır. Uygulama esnasında öğrencilerden dinleme/izleme amaçlarına göre notlar almaları istenir. Not alınırken dikkat etmeleri gereken noktalar (ana fikrin, önemli ifadelerin, güzel sözlerin not alınması; özgün ifadelerin kullanılması vb.) hatırlatılır. Öğrencilere not alabilecekleri çalışma kâğıtları verilir. (MEB, 2006: 62). Öğrencilerin not alarak dinleme/izleme becerilerinin eğitimine yönelik basitten zora çeşitli çalışmalar planlanmalı ve her öğrencinin kendi not alma biçimini geliştirmesine zemin hazırlanmalıdır. Örneğin, öğretmenin rehberliğinde sınıfça bir cümledeki anahtar kelimeleri belirleme çalışması, ardından bir kısa paragraftaki önemli bölümleri belirleme çalışması yapmak, sonrasında ise bir metindeki önemli yerleri tespit etme çalışması yürütmek, öğrencilerin not alınacak yerleri uygulamalı olarak belirlemeleri açısından önemlidir (Doğan, 2013: 33). "Not almak dinlenilen bilgilerin kalıcılığını sağlamada önemli bir yöntem olmakla birlikte ihtiyaca yönelik doğru notları almak zor bir iştir. Dolayısıyla seri bir konuşmanın içinden istenilen ve gerekli bilgileri not alabilmek düzenli ve sistemli bir eğitimle mümkündür. Öğrencilerin özellikle derslerde öğretmenlerinin verdiği bilgi yelpazesinden neyi ne kadar not alacaklarını bilmeleri onların akademik başarılarını olumlu yönde etkileyecektir. $\mathrm{Bu}$ anlamda not alarak dinlemenin boyutları ve farklı tekniklerle not almanın da öğretilmesi gerekir. Klasik not alma tekniklerinin yanı sıra zihinde haritalama, kavram haritası, Cornell tekniği ve benzeri yollarla öğrencilerin dinlediklerini not alma becerileri desteklenmelidir" (Ceran, 2005: 208). 
Kendini Konuşanın Yerine Koyarak Dinleme (Empatik Dinleme): Kendini konuşanın yerine koyarak dinlemede amaç, dinleyicinin kendisini konuşmacının yerine koyarak onun neler hissettiğini, sözlerinin hangi deneyimleri yansıttığını, kendini ve dünyayı nasıl algıladığını anlamaktır. Uygulamada, konuşmacının veya dinlediklerindeki/izlediklerindeki varlık ve şahıslardan birinin yerine kendilerini koyarak olayları, duygu ve düşünceleri anlamaları istenir (MEB, 2006: 62). Bu dinleme türünde, dinleme esnasında belli bir etkileşim vardır ve dinleyicinin aktif ve duygusal katılımı söz konusudur (Bodie, 2011: 278).

Yaratıcı Dinleme: Yaratıcı dinleme, öğrencilerin dinlediklerini/izlediklerini yorumlaması ve bunlardan yeni fikirler üretmesini amaçlar. Bu amaç doğrultusunda, katılımsız dinleme/izleme yapılarak konuşmacının sözlerinden yeni düşünce ve hayaller üretilir veya katılımlı dinleme/izleme yapılarak konuşmacının sözlerinden üretilen düşünce ve hayaller ifade edilir. Konuşmacının daha rahat ve yaratıcı düşünmesini sağlamak için yönlendirici sorular sorulur veya cesaret verici sözler söylenir (MEB, 2006: 63). Yaratıcı dinlemede kişinin dinlediği konu hakkında sunulan argüman, kanıt ve sonuçlarla verilen mesajların ikna edici ve geçerli olup olmadığını sorgulaması esastır (Liubinienė, 2009: 90).

Ayırt Edici (Ayrıştırıcı) Dinleme: Ayırt edici dinlemede ana fikirler ve önceden belirlenmiş görevlere odaklanılır. Dinleyiciler, dinlediklerindeki anahtar bilgileri ortaya çıkarmaya çalışır ve bu bilgileri anlamlı bir biçimde yapılandırır. Ayırt edici dinleme türü, Morley tarafından literatüre kazandırılmış bir kavramdır. Improving Aural Comprehension (1972) adlı eserinde Morley, işitsel anlamayı geliştirmenin temel ilkesinin; kişinin dinlenene konsantre olması, disiplinli biçimde dinlemesi ve verilen dinleme görevlerini en hızlı biçimde yerine getirmesi olduğunu ifade etmiştir (Rost, 2011). Bu nedenle, ayırt edici dinleme gerçekleştiren bireylerin duyma ile ilgili probleminin olmaması, dilin kurallarına hâkim olması, dinlediği kişinin beden dili ile verdiği mesajları göz önünde bulundurması, olumlu, olumsuz cümlelere dikkat etmesi, her şeyden önce hem ruhen hem de bedenen dinlediklerine odaklanması gerekir (Altunkaya, 2018). Ayrıştırıcı dinleme, sesler arasındaki farklılıkları ayırt edebilmedir. Yaşa ve sınıf seviyesine göre ayrıştırıcı dinlemeyi geliştirici etkinlikler de farklılık göstermektedir. Bu dinleme türü, kişilerin ses ve telaffuzları konusundaki fonetik farkındalıklarını arttırmak için de kullanılabilir (Melanlıŏlu, 2011: 72).

Eleştirel Dinleme: Eleştirel dinlemede amaç, öğrencilere dinledikleri/izledikleri hakkında soru sorma alışkanlığı kazandırarak konu hakkında düşünmelerini; konuyu olumlu ve olumsuz yanlarıyla, tarafsız bir bakış açısıyla değerlendirmelerini sağlayarak kendi doğrularını buldurmaktır (MEB, 2006: 63). Kişinin eleştirel dinleme yapabilmesi için konuşmacının amacını, bilgi birikimini, çözüm önerilerini, ön yargılı olup olmadı̆̆ını çok iyi tespit etmesi gerekmektedir (Ungan, 2013). Eleştirel dinleme, dinleyicinin dinlediği mesajı, öncelikle değerlendirerek sonrasında kabul veya reddetmesi şeklinde ifade edilebilir (Feyten, 1991: 174).

Estetik Dinleme: Kişilerin eğlence ve zevk almak için yaptıkları dinlemedir (Kurudayığlu ve Kana, 2013: 247). Bu tür dinlemede mesajın duygu ve heyecan uyandırması beklenir. Bir hikayenin, şarkının, şiirin dinlenmesi estetik dinlemeye örnek olarak verilebilir (Doğan, 2013: 30). Estetik deneyim, kaliteli bir yaşamın en önemli unsurlarından biridir. Dinlemek ise estetik deneyimlerinin kalbi konumundadır (Reese, 1983: 38). Bu nedenle, estetik dinleme yaşamımızda önemli bir yer tutmaktadır.

Bireylerin kullandıkları dinleme türleri, onların dinlediklerini anlamalarını sağlayan en önemli unsurlardandır. Bunun yanında kişiler, baskın bir dinleme tarzına sahip olmakla birlikte birden çok

\footnotetext{
Adres $\mid$ Address

İstanbul Medeniyet Üniversitesi, Eğitim Bilimleri Fakültesi, Türkçe İstanbul Medeniyet University, Faculty of Education Sciences, ve Sosyal Bilimler Eğitimi Bölümü, Türkçe Eğitimi ABD Cevizli Turkish and Social Scinces Education, Turkish Language Teaching Kampüsü, Kartal-İstanbul/TÜRKIYE $\quad$ Education, Cevizli Campus, Kartal-İstanbul /TURKEY e-posta: editor@rumelide.com 1 e-mail: editor@rumelide.com
} 
dinleme stilini kullanıyor olabilir. Tabak'ın (2013: 173) ifadesiyle bir bireyin hangi dinleme stili baskın ise kişi, o dinleme stiline göre nitelendirilmektedir. Ancak bireylerin dinleme stilleri zamana, mekâna, bağlama ve farklı durumlara göre yaşamları boyunca her an değişebilmektedir.

\subsection{Türkçenin yabancı dil olarak öğretiminde dinleme becerisi}

Dinleme, öğrenme-öğretme sürecinde en çok kullanılan dil becerisi olmasının yanı sıra iletişim sürecinin de en önemli ögesidir. Duygu, düşünce, istek ve ihtiyaçların karşıllklı olarak iletilmesi amacıyla başvurulan dinleme, toplumsal ve bireysel ilişkilerde başarılı olmanın da ön şartıdır. Kişilerin hedef dilde iletişim kurabilmesi için de dinlediğini anlaması gerekir (Karakuş Tayşi, 2017: 321). Edinilen ilk beceri olan dinlemenin ana dili gelişimindeki önemi, yabancı dil gelişiminde de geçerlidir. Çünkü dinlediğini anlayabilme, yabancı bir dili öğrenmek için de gereklidir. Hedef dilde girdiyi sağlamak için dinleme becerisine ihtiyaç vardır ve bu özelliğiyle dinleme, diğer becerilerle iç içe ve eş zamanlı ilerlemektedir (Doğan, 2019:69). Dinleme becerisi, hem kişilerarası hem de içsel etkileşimle ilgilidir. Yüz yüze iletişim sırasında kişiler arası etkileşim, dinlenenin beyinde çözümlenmesinde ise içsel iletişim meydana gelir (İnce ve Boztilki, 2016: 158).

Yabancılara Türkçe öğretiminde dinleme becerisinin kazandırılmasında temel amaç, öğrencinin dinlediklerinde geçen kelimeleri tanıması, telaffuz biçimini ayırt etmesi ve verilen iletiyi doğru anlamasını sağlamaktır. Bu şekilde günlük yaşamlarında karşılaşabilecekleri dil kalıplarını öğrenen ve anlayan öğrenciler, bu öğrendiklerini sözlü ve yazılı anlatımlarında uygulama aşamasına geçeceklerdir. İleri düzeyde ise, dinlediklerinde geçen ayrıntıları anlama ve yorumlama becerisi gelişir (Uslu Üstten, 2019: 131).

Yabancı dil öğretiminde dört temel dil becerisinden en zor gelişeni dinleme becerisidir. Dile hâkimiyet ve o dilin yapılarını konuşulduğu esnada tanıma ve seçebilme de dinlenenin anlaşılmasında etkilidir. Bu nedenle dinleme öğretiminde öncelikle dilin fonolojik yapılarının tanınması ve daha sonra bunların ayırt edilmesi önemlidir (Demirel, 2014: 98). Ancak dinleme sırasındaki bu tanıma ve ayırt etme işlemlerinde hedef dili öğrenen bireyler bazı sorunlar yaşamaktadır. Konuya ilişkin Koçer (2013: 167) Türkçeyi yabancı dil olarak öğrenen öğrencilerin dinleme ile ilgili yaşadıkları sorunlardan en önemlisinin öğrencilerin Türkçenin çeşitli ağılarını anlamak olduğunu belirlemiştir.

Yabancllara Türkçe öğretiminde dinleme becerisinin gelişmesi ve dinleme sorunlarının önüne geçilmesi öncelikle öğretim elemanının yeterliğine bağlıdır. Özellikle temel düzeyde öğrencilerin öğretmenlerin konuşmalarını taklit ederek ilk öğrenmelerini gerçekleştirdikleri göz ardı edilmemelidir (Güzel ve Barın, 2013: 269). Bu bağlamda, Türkçeyi yabancı dil olarak öğretecek öğretmenlerin alanında yetkin ve bilinçli olmaları gerekmektedir.

Yabancı dilde sözlü iletişimi gerçekleştirebilmek için öğrencinin o dildeki pek çok bilgi, beceri ve kullanımla karşlaşmasının ve bir süre bunların öğrenciye yüklenmesinin gerektiğini düşünen uzmanlara (Rivers, 1966; Krashen, 1982; Brown, 1987) göre, bu yükleme dil öğreniminim ilk basamağıdır. Ayrıca, konuşulan dil, öğrenci için bir karşılıklı etkileşim aracı olduğu için, tepki geliştirebilmenin ilk koşulu olarak etkiye maruz kalmak ve bu etkiyi doğru yorumlamak gerekmektedir (Güven, 2007: 27). Bu etkileşim sürecinde yeni bir dil öğrenen öğrenciler, en fazla dinleme becerisine maruz kalmaktadır. 
Dinlemenin dil becerileri içinde en zor olanı olduğu kabul edilir ve dinleme çalışmaları her zaman öğrencileri endişelendirir, strese sokar. Ancak dinleme dilin daha kolay öğrenilmesini sağlar. Çünkü bir sözcük, ancak işitildikten sonra doğru sesletilebilir ya da tümcede doğru ezgiler kullanılabilir; aynı zamanda dil bilgisi ögelerinin ve sözcüklerin işlevi gerçek bağlamlarda çözülür. Bu nedenle, gerçek yaşamdan alınmış materyallere gereksinim vardır (Grant, 1991'den akt. Dilidüzgün, 2013: 259). Rost'a (1994) göre yabancı dil öğretiminde dinleme becerisinin geliştirilmesi büyük önem taşır. Otantik dinleme materyallerinin kullanımı, öğrencileri ana dil konuşanlarını anlamaya teşvik eder. Dinleme alıştırmaları ise öğrencilerin sözcük bilgisi, dil bilgisi ve yeni konuşma kalıpları gibi konulara dikkatini çekerek dil öğreticisine kolaylık sağlar. Duman (2013) Türkçenin yabancı dil olarak öğretiminde dinleme becerisi ile ilgili sorunlar yaşayan öğrencilere daha çok işitsel materyallerin sunulması gerektiğini ifade ederek materyal seçiminde öğrenci seviyesi ve ihtiyaçlarının ön planda olması gerektiği üzerinde durmuştur. İşcan (2011) ise Türkçenin yabancı dil olarak öğretiminde dinleme becerisinin gelişimi için video ve filmlerden yararlanılabileceğini ifade etmiş; video ve filmlerin gerçekçi ve güvenilir bir dinleme kaynağı olduğunu, günlük hayattaki diyalogların, eksiltili yapıların, ses tonu ve vücut dili unsurlarının bu kaynaklar sayesinde Türkçe öğrenen öğrencilere sunulabileceğini belirtmiştir.

Yabancı dil öğretiminin başlarında, hedef dili öğrenenlerin tam cümleler yerine söz parçalarını yakalama ihtimalleri daha yüksek olsa da, dinleyiciler jestler ve tonlama gibi ekstra dilsel ipuçlarından faydalanabilirler (Akinnaso, 1985; Sinatra, 1990). Bu nedenle Türkçeyi yabancı dil olarak öğreten öğreticiler, özellikle ilk derslerde anlattıkları konuları jest ve mimikleri ile destekleyerek ilgi dinleme ortamları oluşturabilirler. Öğretmenler ayrıca standart Türkçe ile doğru vurgu ve tonlamaya başvurarak kendilerini ifade ederlerse Türkçeyi yeni öğrenen öğrenciler de doğru ve anlamlı öğrenmeler gerçekleştirebilir.

Ayrıca yabancı dil öğretiminde ilk derslerde;

-herkesi kapsayan yönerge ve talimatların (Lütfen, Oturun, Dinleyin, Defterinizi, kitaplarınızı açın, Sessiz olun ...vb.),

-genel kontroller ve soruların (Hazır mısınz?, Bir problem var mı?, Anladını mı? ...vb.),

-genel geri bildirim ve dönüş cümlelerinin (Harika, Mükemmel, Aferin, Bu doğru, Tekrar söyleyebilir misin?, ... diye söylersen daha iyi olur... vb.) öğretilmesi, dinleme uygulamalarında öğretmen ve öğrencilerin daha kolay iletişim kurmaların sağlayarak öğrencilerin hedef dili bilmemelerinden kaynaklanan iletişim engellerini en aza indirebilir (Ur, 2018).

\section{Okuma}

Literatür incelendiğinde okumaya ilişkin birçok farklı tanıma rastlanmıştır:

Okuma, "bilişsel davranışlarla psikomotor becerilerin ortak çalışmasıyla yazılı sembollerden anlam çlkarma etkinliğidir" (Demirel, 1999:133)

"Okuma, bir yazıyı, sözcükleri, cümleleri, noktalama işaretleri ve öteki ögeleriyle görme, algılama ve kavrama sürecidir” (Kavcar, Oğuzkan, Sever, 2004: 41).

"Okuma; ön bilgilerin kullanıldı̆̆ı, yazar ve okuyucu arasındaki etkili iletişime dayalı, uygun bir yöntem ve amaç doğrultusunda düzenli bir ortamda gerçekleştirilen anlam kurma sürecidir” (Akyol, 2008: 1).

Adres

İstanbul Medeniyet Üniversitesi, Eğitim Bilimleri Fakültesi, Türkçe ve Sosyal Bilimler Eğitimi Bölümü, Türkçe Eğitimi ABD Cevizli Kampüsü, Kartal-İstanbul/TÜRKIYE e-posta: editor@rumelide.com
Address

Istanbul Medeniyet University, Faculty of Education Sciences,

Turkish and Social Scinces Education, Turkish Language Teaching

Education, Cevizli Campus, Kartal-İstanbul /TURKEY

e-mail: editor@rumelide.com 
Okuma; gözlerin ve ses organlarının farklı hareketlerinden ve zihnin anlamı kavramak için verdiği çabadan meydana gelen bir etkinliktir (Arıcı, 2008).

Dil ve kişiliği geliştirmenin en etkili araçlarından birisi olan okuma bir bakıma anlama faaliyetidir (Özbay, 2009b).

Okuma üzerine uzun yillar araştırma yapan Stauffer (1969: 5) öğrencilerinden ve bu konuda uzun yıllar deneyimi olan öğretmenlerden “Okuma nedir?” sorusuna aldığı cevaplardan yola çıkarak okumanın karmaşık bir süreç olduğunu; basılı kelimeyi anlama ve seslendirme becerisini içerdiğini ve işaret harf ve sembollerin ne anlama geldiğini yorumlama işi olduğunu ifade etmiştir (akt. Karatay, 2011: 11).

Dilin mevcudiyeti, onu bir bütün yapan cümlelerden, metinlerden ileri gelmektedir. İnsanlar arası iletişimin gerçekleşmesinde çeşitli becerilerin yanında okuma becerisinin de önemli bir yeri vardır. Okuma becerileri ve okuma edinimi ışığında metinler aracılı̆̆ıyla anlaştığımızı söylemek çok da yanlış olmayacaktır (Gök, 2017). Bir başka ifadeyle, okuma eyleminin, temelde içsel olarak ulaşacağı olası sonuç metin anlamadır. Bu nedenle, tüm bu kavramların işaret ettiği ortak noktadan hareketle okuma, yapısal olarak metin anlama ile ilgili bilişsel bir "iş/eylem” olarak tanımlanabilir. Bir bilişsel eylem olarak okuma, metindeki değişik bilgi kaynakları arasında var olan etkileşimi kavramayı ve anlamayı gerektirir (Uzun, 2009: 9). Okumanın yetkin ve anlamlı bir biçimde gerçekleşmesi için okuyucular, kelime kod çözme ve tanıma süreçlerinde akıcı olmalı, kelime hazinelerini ve bilgi tabanlarını sürekli olarak genişletmeli ve çıkarımlar yapmak ve metni eleştirel olarak analiz etmek için ayrıntılı bilişsel stratejiler kullanmayı öğrenmelidir (Wigfield, Gladstone \& Turci, 2016). Ayrıca yapılan araştırmalar (Rice, 1986; Greaney \& Hegarty, 1987; Anderson, Wilson \& Fielding, 1988) okuma alışkanlığı olan öğrencilerin kelime bilgisi testlerinde daha az okuyan öğrencilerden daha başarılı olduklarını göstermektedir.

Okumak, bireyi sorgulamaya yönlendirdiği zaman hedefine ulaşmış olacaktır. Her bilgiyi kabul etmek ve o bilginin tek doğru olduğunu varsaymak, iyi bir okuyucu için geçerli değildir (Kurudayığlu ve Çelik, 2013: 112). Okumanın asıl amacı, anlamı kavramak olduğuna göre kelime şekillerinin, anlamlarıyla aynı zamanda kavranması gerekir. Anlam, hem kelimelerin özel şekillerini tanıma, hem de söz gelişinden yararlanılması bakımından okumanın en önemli unsurunu teşkil eder. Bu nedenle okuma, belli bir amaca yönelik yapıldı̆̆ zaman daha verimli olmaktadır (Aytaş, 2005: 462). Ayrıca, konuya ilişkin yapılan çalışmalar (Guthrie \& Wigfield, 2000; Alvermann, 2002; Stipek, 2002; Guthrie vd., 2004; Afflerbach \& Cho, 2011, Guthrie, Taboada, \& Wigfield, 2011) okuma becerisinin gelişmesi için öğrencilerin okumaya yetince motive olması ve okuma stratejilerinden yararlanılması; öğretmenlerin ise öğrencilerinin okuma motivasyon, tutum ve alışkanlıklarının farkında olması gerektiğini ifade etmektedir.

\subsection{Türkçenin yabancı dil olarak öğretiminde okuma becerisi}

Yabancı dil öğretiminde öğrenicinin tüm becerileri kazanması hedeflenir. Okuma becerisi özellikle yabancı dil öğretiminde ön plana çıkarak diğer becerilerin de geliştirilmesini etkileyen bir beceridir. Yabancı dilde okuma becerisinin geliştirilmesi diğer becerilerin de daha etkin ve verimli bir duruma gelmesini sağlamaktadır. Bu nedenle okuma becerisine ağırlık verilmesi gerekmektedir (Şen, 2015: 77). Türkçenin yabancı dil olarak öğretiminde okuma süreci; okurun bir yandan ses, hece, kelime bilgisi, cümle yapısı gibi yapıları zihinsel olarak tanımasını, diğer yandan ön bilgilerini, dünya görüşünü de işe koşarak metindeki anlamı kavramasını gerektiren bir süreçtir (Altunkaya ve Erdem, 2017: 60) 
Ana dili eğitiminde okuma eğitiminin amacı genel olarak öğrencilerin anlama becerilerinin geliştirilmesi, öğrencilere okuma alışkanlığı kazandırılması ve onları seçici birer okur yapmak iken yabancı dilde okuma eğitiminin daha çok öğrencilerin anlama becerilerini geliştirmeye yönelik olduğu söylenebilir (Pang S., vd., 2012'den akt. Tüfekçioğlu, 2013).

Yaylı (2011: 59) ana dili ve yabancı dilde okuma farklılıklarını şu şekilde özetlemiş̧tir:

Dilbilimsel ve İşlemsel Farklılıklar:

Sözcük bilgisi, dil bilgisi ve söylem bilgisi

Ana dili ile yabancı dil arasındaki dil bilimsel farklılık düzeyi

Üst-dil bilimsel ve üstbilişsel farkındalık

Yabancı dil yeterlilik düzeyi

Dile maruz kalma düzeyi

Transfer

\section{Bireysel ve Deneyimsel Farkllhklar}

Bireysel beceri ve güdülenme

Metin türleri

Kaynaklar

\section{Sosyo-Kültürel ve Kurumsal Farkhlhklar}

Okurların farklı sosyo-kültürel geçmişleri

Farklı söylem ve metin oluşturma yolları

Eğitim kurumlarının farklı beklentileri

Yabancı dil dersinde metinlerle çalışırken okuma becerisini geliştirmeye yönelik adımlar okuma öncesini, okuma esnasını ve okuma sonrasını ayrı ayrı ele almayı gerektirir. Okuma öncesinde yer alan çalışmaların temel amacı, okuyucunun dünya bilgisini harekete geçirmek ve okuma nedenlerini belirlemektir. Bu çalışmalar sayesinde okur, hangi konuda metin okuyacağını sezmekte ve bu konuya ilişkin var olan bilgilerini harekete geçirmektedir (Özdemir, 2010: 41-42). Okuma sırasındaki etkinliklerde öğrencilerin okuduklarını anlamaları ve yazarın iletmek istediği mesajı almaları istenir. Bu aşamada öğrencinin yapmasını istenebilecek etkinlikler şunlardır:

1. Anlamı bilinmeyen kelimelerin anlamlarının tahmin edilmesi,

2. Zor anlaşılabilecek cümlelerdeki kişi zamirlerinin hangi ismin yerine kullanıldığının bulunması,

3. Detaylı sorulara yanit aranması,

4. Ana düşünce ve yardımcı fikirlerin araştırılması,

5. Yazarın üslubuna dikkat edilmesi,

6. Not tutulması ve önemli düşüncelerin olduğu bölümlerin altının çizilmesi (Demirel, 1999:136)

Okuma sonrasındaki aşamada amaç, öğrenilen dilin dil bilgisi kurallarını pekiştirmek ve okuma becerilerini geliştirmektir. Öğrencinin yapmasını isteyebileceğimiz etkinlikler şunlardır:

1. Metinle ilgili sorulan detaylı sorulara doğru cevap verilmesi,

\footnotetext{
Adres $\mid$ Address

İstanbul Medeniyet Üniversitesi, Eğitim Bilimleri Fakültesi, Türkçe İstanbul Medeniyet University, Faculty of Education Sciences, ve Sosyal Bilimler Eğitimi Bölümü, Türkçe Eğitimi ABD Cevizli Turkish and Social Scinces Education, Turkish Language Teaching Kampüsü, Kartal-İstanbul/TÜRKIYE $\quad$ Education, Cevizli Campus, Kartal-İstanbul /TURKEY e-posta: editor@rumelide.com 1 e-mail: editor@rumelide.com
} 
2. Ana düşünce ve yardımcı fikirlerin neler olduğunun belirtilmesi,

3. Metindeki bilginin şekil, akışşseması gibi farklı şekillerde sunulması,

4. Metnin giriş, gelişme ve sonuç kısımlarının ana çerçevesinin tespit edilmesi,

5. Okunan metnin öğrenci tarafından özetlenmesi,

6. Metinde geçen olaya ilişkin bir kompozisyon yazılması (Özdemir, 2010)

Grabe (2009: 447), okuma sürecinde yaşanan zorluklarla birlikte okuyucunun sahip olduğu birikim, beceri ve yeteneklerin önemine işaret ederek yabancı dilde okuma yapanların okumalarında bulundurdukları altı özellik belirlemiştir:

1. İkinci dil öğreniminde, öğrencilerin kelime dağarcıkları, söz dizimi bilgileri ve dilin yapısına ilişkin farkındalıkları sınırlıdır.

2. İkinci dil öğreniminde öğrenciler, genellikle yabancı dildeki okuma konusunda daha az tecrübeye sahiptirler.

3. İkinci dil öğrencileri, yabancı dilde okumayı farklı șekilde tecrübe edeceklerdir. Çünkü okumayı iki farklı dilde deneyimleyecek ve zihinlerindeki bilişsel işlemler iki dil sistemini ihtiva edecektir.

4. İkinci dil öğrencileri, bir dizi aktarım problemleri yaşayacaklardır.

5. İkinci dil okuyucuları, yabancı dil metinlerinde, kendilerine tanıdık gelmeyen veya kabullenmekte güçlük yaşayacakları toplumsal veya kültürel varsayımlarla karşılaşacaklardır (akt. Altunkaya, 2015: 50-51).

Sonuç olarak ana dili ve ikinci dilde okuma süreçlerinde öğrencilerin dilin kelime bilgisi, dil bilgisi ve söylem yapısına ilişkin bilgilerin varlığı/yokluğu konusunda farklılıklar gözlemlenmektedir. Ana dilde okuma etkinliklerine başlarken ana dili konuşucusu, dilin söz konusu özelliklerini örtük olarak bilmektedir. Ancak ikinci dil edinim sürecinde erek dile ilişkin beceriler eş zamanlı olarak edinilmeye başlandığı için ikinci dil edinicileri bu bilgilere henüz sahip değillerdir. Bu durum da, ikinci dildeki okuma sürecinin ana dildeki okuma sürecine göre daha zor ve karmaşık bir yapıya sahip olduğunu göstermektedir (Aygüneş, 2007: 51-52).

\section{Sonuç ve öneriler}

Kişi, işitme ve konuşmasını sağlayacak araçlara doğduğu anda sahiptir, dolayısıyla bireyin duyması ve konuşması için toplum içerisinde yaşamaktan başka çabaya ihtiyacı yoktur. Ancak kanal olarak kullanılan dilin etkili bir iletişim aracı haline gelmesi için dilin anlama ve anlatma becerilerinin geliştirilmesi gerekmektedir (İşcan ve Aydın, 2014: 321). Anlama becerileri kapsamına "dinleme" ve "okuma" becerileri girmektedir.

Dinleme becerisinin geliştirilmesi kişilerin yalnızca akademik başarılarını arttırmasının ötesinde günlük yaşamdaki iletişim sorunlarının giderilmesi ve toplumda başarılı sosyal ilişkilerin geliştirilmesinde de önemli bir role sahiptir. Dinleme becerisi, Türkçenin yabancı dil olarak öğretimde en zor gelişen becerilerden biridir. Çünkü Türkçeyi öğrenen bireyler; bu dilin ses, şekil ve cümle yapılarına yeterince hâkim olmamalarının yanı sıra günlük yaşamda birçok farklı ortamda işitsel mesajlara muhatap olmaktadırlar. Bu mesajların büyük çoğunluğu, kişilerin aşina olmadıkları sosyal ve kültürel içerikler barındırabilir. Bu nedenle bu mesajların algılanıp anlamlandırılması sürecinde kişiler güçlük yaşayabilir. Bunun yanında, bireylerin okul dışında karşılaştıkları dil, çoğu zaman ölçünlü değil farklı ağız özelliklerini yansıtmaktadır. Bu durum da öğrencilerin dinleme becerisinin gelişiminde karşılaştıkları güçlüklerdendir. Zamanla Türkçenin kurallarını öğrenerek aynı kültürel ortamı paylaşan bireylerin dinleme becerileri de buna bağlı olarak günden güne gelişebilmektedir. Bu 
süreçte öğrencilerin işitsel mesajları alabilecekleri sosyal ortamlara daha fazla girmeleri, dinleme becerisinin gelişiminde daha hızlı mesafe kat edilmesini sağlayabilir. Ayrıca sunulan dinleme materyallerinin görsel unsurlarla, jest ve mimiklerle desteklenmesi de dinleme becerisinin gelişimine katkı sağlayabilir.

Türkçenin yabancı dil olarak öğretiminde okuma becerisinin geliştirilmesi büyük önem taşımaktadır. Çünkü okuma becerisinin gelişmesiyle diğer becerilerinin gelişimine de bir zemin hazırlanacaktır. Yabancı dil öğretiminde okuma becerisinin geliştirilmesi için öncelikle bireylerin hedef dildeki metinleri doğru biçimde anlamaları gerekmektedir. Bu okuduğunu anlama işleminde kişinin kelime hazinesinin yeterli düzeyde olması, cümle yapısının ve dil bilgisi özelliklerinin öğrenci tarafından belirli bir düzeyde bilinmesi gerekir. Ayrıca, okunan metinlerdeki içeriğin de öğrencilerin ön bilgilerine uygun olması önemlidir.

Sonuç olarak ana dili ve ikinci dildeki okuma-anlama süreci, okurların farklı türde metinlere farklı yaklaşımlar geliştirmesi açısından birbirine benzerdir. Ancak ikinci dil edinim sürecinde dil edinicilerinin sınırlı sayıda metin türüyle ve genellikle çeşitli açılardan değiştirilmiş metinlerle karşılaşması açısından bu okuma süreci ana dildeki okuma sürecinden bir ölçüde ayrılmaktadır. Ayrıca ana dildeki okuma sürecinde zorluk, uzunluk, biçim açısından çok sayıda farklı metinlerle karşılaşılırken ikinci dilde nicelik açısından daha kısıtlı metinlere karşılaşılmakta, bu durum da ana dil ve ikinci dil edinicilerinin okuma etkinliğinden edindikleri deneyim düzeylerinin farklllaşmasına neden olmaktadır (Aygüneş, 2007: 72). Bu bağlamda, Türkçeyi yabancı dil olarak öğreten bireylerin bu farklılaşmaları dikkate alarak okuma etkinliklerini tasarlamaları ve Türkçeyi yeni öğrenen öğrencilerin yaşadıkları okuma güçlüklerinin giderilmesi noktasında öğrencilere yardımcı olmaları gerekmektedir. Bu bağlamda dil öğreticilerinin alfabeden başlayarak söz varlığı, vurgu ve tonlama ile bilgiler vermesi ve ilgili konulara ilişkin tüm öğrencilerin yer aldığı uygulamalar yapmaları, öğrencilerin okuma becerilerinin gelişimine önemli katkı sağlayabilir.

\section{Kaynaklar}

Afflerbach, P.P., \& Cho, B.Y. (2011). The classroom assessment of reading. In M.L. Kamil, P.D. Pearson, E.B. Moje, \& P.P. Afflerbach (Eds.), Handbook of reading research (Vol. 4, pp. 487 514). New York, NY: Routledge/Taylor \& Francis.

Akinnaso, N. F. (1985). On the similarities between spoken and written language. Language and Speech, 28, 323-359.

Akyol, H. (2006). Türkçe öğretim yöntemleri. Ankara: Kök.

Akyol, H. (2008). Türkçe ilk okuma yazma öğretimi. Ankara: Pegema.

Akyol, H. (2014). Türkçe öğretim yöntemleri. Ankara: Pegem Akademi.

Altunkaya, H. (2015). Yabancı dil olarak Türkçe öğrenenlerin okuma kaygıları ile okuduğunu anlama becerileri arasındaki ilişki. Yayımlanmamış Doktora Tezi, İnönü Üniversitesi Eğitim Bilimleri Enstitüsü, Malatya.

Altunkaya, H. ve Erdem, İ. (2017). Yabancı dil olarak Türkçe öğrenenlerin okuma kaygıları ve okuduğunu anlama becerileri. Sakarya University Journal of Education, 7(1), 59-77.

Altunkaya, H. (2018). Dinleme türleri. A. Akçay (Ed.), Dinleme izleme eğitimi içinde (s. 77-115). Ankara: Nobel Akademik.

Alvermann, D. E. (2002). Effective literacy instruction for adolescents. Journal of Literacy Research, $34(2), 189-208$.

\footnotetext{
Adres $\mid$ Address

İstanbul Medeniyet Üniversitesi, Eğitim Bilimleri Fakültesi, Türkçe İstanbul Medeniyet University, Faculty of Education Sciences, ve Sosyal Bilimler Eğitimi Bölümü, Türkce Eğitimi ABD Cevizli Turkish and Social Scinces Education, Turkish Language Teaching Kampüsü, Kartal-İstanbul/TÜRKIYE $\quad$ Education, Cevizli Campus, Kartal-İstanbul /TURKEY e-posta: editor@rumelide.com 1 e-mail: editor@rumelide.com
} 
Anderson, R., Wilson, P. \& Fielding, L. (1988). Growth in reading and how children spend their time outside of school. Reading Research Quarterly, 23, 285-303.

Arıcı, A. F. (2008). Okuma eğitimi. Ankara: Pegem Akademi.

Aygüneş, M. (2007). Yabancı dil olarak Türkçenin öğretiminde okuma becerisini geliştirme yolları. Yayımlanmamış Yüksek Lisans Tezi, Dokuz Eylül Üniversitesi Eğitim Bilimleri Enstitüsü, İzmir.

Aytaş, G. (2005). Okuma eğitimi. Türk Eğitim Bilimleri Dergisi, 3(4), 461-470.

Bodie, G. D. (2011). The Active-empathic listening scale (AELS): Conceptualization and evidence of validity within the interpersonal domain. Communication Quarterly, 59(3), 277-295.

Brown, G. (1987). Twenty-five years of teaching listening comprehension. English Teaching Forum. 25(1): 11-15.

Bulut, B. (2013). Etkin dinleme eğitiminin dinlediğini anlama, okuduğunu anlama ve kelime hazinesi üzerine etkisi. Yayımlanmamış Yüksek Lisans Tezi, Adnan Menderes Üniversitesi Sosyal Bilimler Enstitüsü, Aydın.

Ceran, D. (2015). Seçici dinleme ile not alarak dinleme yöntemlerinin altıncı sınıf öğrencilerinin dinlediğini anlama becerisine etkisi. Zeitschrift für die Welt der Türken/Journal of World of Turks, 7(1), 205-219.

Çifçi, M. (2001). Dinleme eğitimi ve dinleme eğitimini etkileyen faktörler. Afyon Kocatepe Üniversitesi Sosyal Bilimler Dergisi, 2(2), 165-177.

Çiftçi, Ö. (2007). Aktif dinleme. Milli Eğitim, 176, 231-242.

Demirel, Ö. (1999). İlköğretim okullarında yabancı dil öğretimi. İstanbul: MEB.

Demirel, Ö. (2014). Yabancı dil öğretimi (8. Baskı). Ankara: Pegem Akademi.

Dilidüzgün, Ş. (2013). Dinleme eğitimi. M. Durmuş ve A. Okur (Ed.), Yabancılara Türkçe öğretimi el kitabı içinde (s. 259-276). Ankara: Grafiker.

Doğan, B. (2019). Yabancı dil olarak Türkçenin öğretiminde dinleme/izleme eğitimi ve etkinlik örnekleri. İ. Erdem, B. Doğan ve H. Altunkaya (Ed.), Yabancı dil olarak Türkçe öğretimi içinde (s. 69-94). Ankara: Pegem Akademi.

Doğan, B. ve Erdem, İ. (2017). Ortaokul öğrencilerinin dinleme/izleme stratejileri kullanım sıklı̆̆ı ölçeğinin geçerlik güvenirlik çalışması, E-Uluslararası Eğitim Araştırmaları Dergisi, 2(1), 6481.

Doğan, B. ve Erdem, İ. (2018). Strateji temelli dinleme etkinliklerinin yedinci sinıf öğrencilerinin dinleme becerisiyle strateji kullanma düzeyine etkisi. International Journal of Language Academy, 6(1), 289-315.

Doğan, Y. (2013). Dinleme eğitimi (3. Baskı). Ankara: Pegem Akademi.

Duman, G. B. (2013). Türkçenin yabancı dil olarak öğretiminde materyal geliştirme ve materyallerin etkin kullanımı. Ana Dili Eğitimi Dergisi, 1(2), 1-8.

Durmuş, M. (2013). Yabancılara Türkçe öğretimi (2. Baskı). Ankara: Grafiker.

Epçaçan, C. (2013). Temel bir dil becerisi olarak dinleme ve dinleme eğitimi. Adıyaman Üniversitesi Sosyal Bilimler Enstitüsü Dergisi, 2013(11), 331-352.

Ergin, A. (2008). Eğitimde etkili iletişim (4. Baskı), Ankara: Anı.

Ergin, A. ve Birol, C. (2000). Eğitimde iletişim. Ankara: Anı.

Feyten, C. M. (1991). The power of listening ability: An overlooked dimension in language acquisition. The Modern Language Journal, 75(2), 173-180.

Ford, W. S. Z., Wolvin, A. D. ve Chung, S. (2000). Students' self-perceived listening competencies in the basic speech communication course. International Journal of Listening, 14(1), 1-13. 
Gök, B. (2017). Yabancı dil olarak Türkçe öğretiminde metin seçimi. Yayımlanmamış Yüksek Lisans Tezi, İstanbul Üniversitesi Sosyal Bilimler Enstitüsü, İstanbul.

Greaney, V. \& Hegarty, M. (1987). Correlations of leisure-time reading. Journal of Research in Reading 10, 3-20.

Guthrie, J. T., Wigfield, A., Barbosa, P., Perencevich, K. C., Taboada, A., Davis, M. H., Scafiddi, N.T. \& Tonks, S. (2004). Increasing reading comprehension and engagement through concept-oriented reading instruction. Journal of educational psychology, 96(3), 403.

Guthrie, J.T., \& Wigfield, A. (2000). Engagement and motivation in reading. In M.L. Kamil, P.B. Mosenthal, P.D. Pearson, \& R. Barr (Eds.), Handbook of reading research (Vol. 3, pp. 403422). Mahwah, NJ: Erlbaum.

Guthrie, J.T., Taboada, A., \& Wigfield, A. (2011). Alignment of cognitive processes in reading with motivations for reading. In D. Lapp \& D. Fisher (Eds.), Handbook of research on teaching the English language arts (3rd ed., pp. 125-131). Mahwah, NJ: Erlbaum.

Gündüz, O. ve Şimşek, T. (2014). Anlama teknikleri 2: Dinleme eğitimi el kitabı. Ankara: Grafiker.

Güneş, F. (2013). Türkçe öğretimi yaklaşımlar ve modeller. Ankara: Pegem Akademi.

Güven, Z. Z. (2007). Öğrenme stillerine dayalı etkinliklerin öğrencilerin dinleme becerisi erişileri, İngilizce dersine yönelik tutumları ve öğrenilenlerin kahculı̆̆na etkisi. Yayımlanmamış Doktora Tezi, Selçuk Üniversitesi Sosyal Bilimler Enstitüsü, Konya.

Güzel, A. ve Barın, E. (2013). Yabancı dil olarak Türkçe öğretimi. Ankara: Akçağ.

İnce, B. ve Boztilki, G. (2016). Yabancı dil olarak Türkçe öğretiminde dinleme becerisi. F. Yıldırım ve B. Tüfekçioğlu (Ed.), Yabancı dil olarak Türkçe öğretimi kuramlar yöntemler yaklaşımlar beceriler uygulamalar içinde (ss. 157-175). Ankara: Pegem Akademi.

İşcan, A. (2011). Yabancı dil olarak Türkçe öğretiminde filmlerin yeri ve önemi. Turkish Studies International Periodical for he Languages, Literature and History of Turkish or Turkic, 6(3), 939-948.

İşcan, A. ve Aydın, G. (2014). Yabancı dil olarak Türkçe dinleme öğretimi. A. Şahin (Ed.), Yabancı dil olarak Türkçe öğretimi kuramlar, yaklaşımlar, etkinlikler içinde (s. 317-335). Ankara Pegem Akademi.

Karakuş Tayși, E. (2017). Dil becerileri-anlama (Dinleme ve okuma becerileri). H. Develi, C. Yıldız, M. Balcı, I. Gültekin ve D. Melanlığlu (Ed.), Uygulamah Türkçenin yabancı dil olarak öğretimi el kitabı Cilt 1 içinde (s. 289-358). Ankara: Kesit Yayınları.

Karatay, H. (2011). Okuma eğitimi kuram ve uygulama. Ankara: Berikan.

Kavcar, C., Oğuzkan F. ve Sever, S. (2004). Türkçe öğretimi. Ankara: Engin.

Kaya, M. F. (2014). Dinleme türleri ölçeğinin Türk kültürüne uyarlanması, dil geçerliği ve faktör yapısının belirlenmesi. Abant İzzet Baysal Üniversitesi Sosyal Bilimler Enstitüsü Dergisi, 14(3), 321- 340

Koçer, Ö. (2013). Program geliştirmenin ilk basamağı: Yabancı dil olarak Türkçe öğretiminde ihtiyaç ve durum analizi. Ĕgitim ve Bilim, 38(169).

Krashen, S. (1982). Principles and practice in second language acquisiton. Oxford: Pergamon.

Kurudayığlu, M. ve Çelik, G. (2013). Türkçe öğretmeni adaylarının okumaya ve okuma eğitimine ilişkin öz yeterlik algıları. Uşak Üniversitesi Sosyal Bilimler Dergisi, 6(4), 109-138.

Kurudayığlu, M. ve Kana, F. (2013). Türkçe öğretmeni adaylarının dinleme becerisi ve dinleme eğitimi özyeterlik algıları. Mersin Üniversitesi Ĕ̈itim Fakültesi Dergisi, 9(2), 245-258.

Liubinienè, V. (2009). Developing listening skills in CLI. Kalbų studijos, (15), 89-93.

\footnotetext{
Adres $\mid$ Address

İstanbul Medeniyet Üniversitesi, Eğitim Bilimleri Fakültesi, Türkçe İstanbul Medeniyet University, Faculty of Education Sciences, ve Sosyal Bilimler Eğitimi Bölümü, Türkce Eğitimi ABD Cevizli Turkish and Social Scinces Education, Turkish Language Teaching Kampüsü, Kartal-İstanbul/TÜRKIYE $\quad$ Education, Cevizli Campus, Kartal-İstanbul /TURKEY e-posta: editor@rumelide.com 1 e-mail: editor@rumelide.com
} 
Maden, S. ve Durukan, E. (2011). Türkçe öğretmeni adaylarının dinleme stillerinin çeşitli değişkenler açısından değerlendirilmesi. Mehmet Akif Ersoy Üniversitesi Sosyal Bilimler Enstitüsü Dergisi, (4), 101-112.

MEB (2006). İlköğretim Türkçe dersi (6, 7, 8. sinıflar) öğretim programı. Ankara: Milli Eğitim Basimevi.

Melanlığlu, D. (2011). İlköğretim Türkçe öğretim programının "dinleme türleri” bakımından değerlendirilmesi. İnönü Üniversitesi Eğitim Fakültesi Dergisi, 12(3), 65-78.

Mete, F. ve Bağcı Ayrancı. B. (2016). Lisans öğrencilerinin dinleme becerisi üzerine görüşleri. Journal of Human Sciences, 13(3), 4959-4972

Morley, J. (1972) Improving aural comprehension. Ann Arbor, MI: University of Michigan Press.

Özbay, M. (2005). Bir dil becerisi olarak dinleme eğitimi, Ankara: Akçă̆.

Özbay, M. (2009a). Anlama teknikleri II: Dinleme eğitimi. Ankara: Öncü Kitap.

Özbay, M. (2009b). Okuma eğitimi. Ankara: Öncü Kitap.

Özbay, M. ve Çetin, D. (2013). Dinleme becerisinin geliştirilmesinde prozodik farkindaliğin önemi. Sosyal ve Beşeri Bilimler Araştirmalari Dergisi, 26, 155-175.

Özdemir, S. (2010). Yabancı dil olarak Türkçenin öğretiminde halk hikayelerinden yararlanma. Yayımlanmamış Yüksek Lisans Tezi, Dokuz Eylül Üniversitesi Eğitim Bilimleri Enstitüsü, İzmir.

Pearce, C. G., Johnson, I. W. ve Barker, R. T. (2003). Assessment of the listening styles inventory: Progress in establishing reliability and validity. Journal of Business and Technical Communication, 17(1), 84-113.

Pitre, E. (2007). Three Types of Listening. https://cob.unt.edu/mgmt/pitre/mgmt3330/Types\%20Of\%2oListening.pdf (Erişim tarihi 05.01.2019)

Purdy, M. (1997). What is listening. Listening in everyday life: A personal and professional approach, 2, 1-20.

Reese, S. (1983). Teaching aesthetic listening. Music Educators Journal, 69(7), 36-38.

Rice, G. E. (1986). The everyday activities of adults: Implications for prose recall. Educational Gerontology, 12, 173-86.

Rivers, W. (1966). Listening comprehension. Modern Language Journal, 5o(4): 196-204.

Rost, M. (1994). Introducing listening. London: Penguin.

Rost, M. (2011). Teaching and researching (Second Edition). Harlow: Pearson Education Limited

Sarikaya, B. (2018). Dinlemeyle ilgili temel kavramlar. A. Akçay (Ed.) Dinleme/izleme eğitimi içinde (s. 55-75). Ankara: Nobel Akademik.

Sever, S. (2004). Türkçe öğretimi ve tam öğrenme, Ankara: Anı.

Sinatra, G. M. (1990). Convergence of listening and reading processing. Reading Research Quarterly, $25,115-130$.

Stipek, D. (2002). Good instruction is motivating. in A. Wigfield \& J. S. Eccles (Eds.), Development of achievement motivation (pp. 309-332). San Diego, CA: Academic Press.

Şahin, A. (2011). İlköğretim 6. sınıf öğrencilerinin dinleme becerisi farkındalıklarının sosyo-ekonomik düzeye göre incelenmesi. Çankırı Karatekin Üniversitesi Sosyal Bilimler Enstitüsü Dergisi, 2(1), 178-188.

Şen, E. (2015). Yabancı dil olarak Türkçe öğretiminde okuma becerisini geliştirmek üzere "bellek stratejilerinin" kullanımı. E-Dil Dergisi, 4, 64-83. 
Tabak, G. (2013). Türkçe öğretmeni adaylarının dinleme stillerinin bazı değişkenler açısından değerlendirilmesi. Mustafa Kemal Üniversitesi Sosyal Bilimler Enstitüsü Dergisi, 10(22), 171181.

Tomlinson, B. (Ed.). (2011). Materials development in language teaching. Cambridge University Press.

Tompkins, G. E. (2005). Language arts: Patterns of practice. Pearson/Merrill/Prentice Hall.

Tüfekçioğlu, B. (2013). Yabancı dil olarak Türkçe okuma becerisinin yöntem ve materyal açısından geliştirilmesine yönelik bir çalışma. E-Dil Dergisi, 1, 101-117.

Ungan, S. (2013). Dinleme. A. Kırkkılıç, H. Akyol (Ed.), İlköğretimde Türkçe öğretimi (ss. 135-161). Ankara: Pegem Akademi.

Ur, P. (2018). Dil öğretiminde 100 temel strateji. M. Demirtekin (Çev.), Konya: Eğitim.

Uslu Üstten, A. (2019). Yabancı dil olarak Türkçe öğretiminde ölçme ve değerlendirme. Ü. Şen (Ed.), Yabancı dil olarak Türkçe öğretimi içinde (ss. 119-138). Ankara: Pegem Akademi.

Uzun, G. L. (2009). Yaratıcı bir süreç olarak okuma. Dil Dergisi, (143), 7-19.

Ünalan, Ş. (2006). Türkçe öğretimi. Ankara: Nobel.

Vandergrift, L. ve Goh, C. C. (2012). Teaching and learning second language listening: Metacognition in action. New York: Routledge.

Wigfield, A., Gladstone, J. R., \& Turci, L. (2016). Beyond cognition: Reading motivation and reading comprehension. Child development perspectives, 10(3), 190-195.

Yalçın, A. (2002). Türkçe öğretim yöntemleri yeni yaklaşımlar. Ankara: Akçağ.

Yaylı, D. (2011). Ana dilinde ve yabancı dilde okuma. D. Yaylı ve Y. Bayyurt (Editörler). Yabancılara Türkçe öğretimi politika yöntem ve beceriler. İkinci Baskı. Ankara. Anı, 57-70. 